University of Wyoming College of Law

Law Archive of Wyoming Scholarship

$3-27-2006$

\title{
MacCrate (In)Action: The Case for Enhancing the Upper-Level Writing Requirement in Law Schools
}

Kenneth D. Chestek

University of Wyoming College of Law, kchestek@uwyo.edu

Follow this and additional works at: https://scholarship.law.uwyo.edu/faculty_articles

\section{Recommended Citation}

Chestek, Kenneth D., "MacCrate (In)Action: The Case for Enhancing the Upper-Level Writing Requirement in Law Schools" (2006). Faculty Articles. 32.

https://scholarship.law.uwyo.edu/faculty_articles/32

This Article is brought to you for free and open access by the UW College of Law Faculty Scholarship at Law Archive of Wyoming Scholarship. It has been accepted for inclusion in Faculty Articles by an authorized administrator of Law Archive of Wyoming Scholarship. 


\section{MacCrate (in)Action: The Case for Enhancing the Upper-Level Writing Requirement in Law Schools}

Abstract: In 2001, the American Bar Association amended the Standards for Accreditation of Law Schools to require, for the first time, a "rigorous writing experience after the first year." During the summer of 2004 the author conducted a nationwide survey to determine how law schools responded to this change. The author found that most schools did little more than to require students to take at least one course which was evaluated by means of an academic paper rather than an examination. The author concludes that this is probably not the response the ABA had hoped for, but suggests that a 2005 amendment to the Standards, which now require "writing in a legal context", holds more promise for encouraging law schools to focus more on practical legal writing skills. 


\title{
MacCrate (in)Action: The Case for Enhancing the Upper-Level Writing Requirement in Law Schools
}

\author{
by Kenneth D. Chestek ${ }^{*}$
}

Imagine, for a moment, that medical schools had evolved in the same manner that law schools did. Instead of a relatively brief period of teaching the students "basic science," followed by several years of intensive, supervised training on live patients, medical students in this imaginary world would focus most of their attention throughout their education on scientific methods, theory, and discerning the origins of disease. All students would be required to engage in research attempting to discover new diseases or new treatments for known diseases or injuries, and to write a paper describing their findings and theories. Only a relatively few students would ever get to apply their theoretical learning in "live patient clinics;" no student would be required to have such an experience while in medical school.

Would you entrust your health to a new medical school graduate?

Most of us would not. This, however, is exactly what the legal academy is expecting the consumers of legal services to accept from new law school graduates.

Many commentators have described, and lamented, the gap between the legal academy and the practice of law. ${ }^{1}$ This article takes a more hopeful approach. It appears that the American

"Clinical Associate Professor of Law, Indiana University School of Law-Indianapolis. The author wishes to thank Maria Crist, Jo Anne Durako, Pamela Lysaght, Allison Martin, Deborah McGregor, Richard Neumann, and Joel Schumm for reviewing early drafts of this article and providing helpful comments. He also wishes to thank Lauren Dougherty, JD Candidate at Indiana University School of Law - Indianapolis (Class of 2006) for her invaluable assistance in drafting the survey, tabulating the responses and assisting in the evaluation of the data gathered.

${ }^{1}$ See, e.g., Wallace Loh, Symposium on the $21^{\text {st }}$ Century Lawyer: Introduction: The MacCrate Report-Heuristic or Prescriptive?, 69 WASH. L. Rev. 505 (1994); Alex M. Johnson, Jr., Think Like a Lawyer, Work Like a Machine: The Dissonance Between Law School and Law 
Bar Association, which accredits law schools, has been attempting to nudge law schools toward offering, and even requiring, more and more practical legal education, to teach law students to be able to competently perform the tasks they will need in practice. The process has been excruciatingly slow, however. This article will examine one recent attempt by the ABA to move schools in the direction of more practical education (in this case, the 2001 amendment to the ABA Standards for Accreditation, which for the first time required an "additional rigorous writing experience after the first year"), to see if it had the intended effect. I conclude that the amendment had little or no effect on how law schools educate law students in practice skills, and suggest that this was a missed opportunity to move schools toward a more practical approach to legal education. I suggest further, however, that the 2005 amendments to the Standards and their Interpretations have put increased emphasis on the need for law school to invest the upper-level writing requirement with additional "rigor."

\section{Introduction}

As noted above, many commentators have suggested that there exists a gap between academia and the practice of law. In 1989, the American Bar Association's Council of the Section of Legal Education and Admissions to the Bar established The Task Force on Law Schools and the Profession: Narrowing the Gap. Chaired by Robert MacCrate, Esq., the task force began its work in May of that year and conducted a comprehensive study of what skills and values lawyers need at a minimum to competently handle legal matters. It ultimately released, in July of 1992, a report that catalogued those necessary skills and values, and discussed how law

Practice, 64 S. Cal. L. Rev. 1231 (1991); Carrie Menkel-Meadow, Can a Law Teacher Avoid Teaching Legal Ethics?, 41 J. Legal Educ. 3 (1991); Harry T. Edwards, The Growing Disjunction Between Legal Education and the Legal Profession, 91 Mich. L. ReV. 34 (1992); Nancy L. Schultz, How Do Lawyers Really Think?, 42 J. LegaL Educ. 57 (1992). 
schools do, as well as should, teach them. ${ }^{2}$ The report included 25 recommendations specifically geared toward "enhancing professional development during the law school years"; many of these recommendations suggested ways in which the teaching of practical lawyering skills, including legal writing, could be enhanced. ${ }^{3}$

One of the effects of that report has been an ever-increasing focus on so-called "skills education"4 in law schools. ${ }^{5}$ Indeed, one of the recommendations of the MacCrate Commission

${ }^{2}$ American Bar Association, Section of Legal Education and Admissions to the Bar, Legal Education and Professional Development-An Educational Continuum (ABA 1992) (hereinafter "the MacCrate Report"). The report includes a list of ten "fundamental lawyering skills" that every lawyer needs to competently represent clients; $i d$. at $138-140$. The list includes such practical concepts as "problem solving," "factual investigation," "counseling," "negotiation," and "organization and management of legal work," in addition to the more traditional skills of "legal analysis and reasoning" and "legal research" that law schools historically have required students to master.

${ }^{3} I d$., pp. 330-334.

${ }^{4}$ I do not consider the term "skills education" to be derogatory in any sense. Indeed, in most professions, to be called "skillful" is a high compliment. Some in the legal academy, of course, fear that law schools that focus more on skills risk turning into mere "trade schools." A full discussion of the tension between "practice-oriented" law schools and "academic" or "graduate school" models is beyond the scope of this article. It suffices for present purposes to acknowledge that I believe most law schools can, and should, do more to prepare law students for what they will face upon graduation. For an interesting discussion of the tension between practice and academic orientations, see Laurel Terry, Taking Kronman and Glendon One Step Further: in Celebration of "Professional Schools," 100 Dick. L. REv. 647, 670, n. 63 (1996) (in which the author suggests that the legal world needs both "research law schools" and "professional" or "teaching law schools," but probably more of the latter). For a contrary view, see Henry Ramsey, Jr., Speech: The History, Organization, and Accomplishments of the American Bar Association Accreditation Process, 30 WAKe Forest L. Rev. 267, 279 (1995) (suggesting with alarm that a "few, but vocal and aggressive [group of] lawyers among the practicing bar" seek to force the ABA "to recognize the practitioner's right to require the teaching of particular skills courses and other subjects by the law schools.").

${ }^{5}$ Michael M. Bowden, The New Breed of Law Grad, 99 LAw. WkLy. USA 318 (Apr. 5, 1999) [http://www.lawyersweeklyusa.com/nlsgs1.cfm]; see also Russell Engler, The MacCrate Report Turns 10: Assessing its Impact and Identifying Gaps We Should Seek to Narrow, 8 
was to amend Standard 301 of the Standards and Interpretations for the Approval of Law Schools to clarify that at least part of the mission of law schools would be "to prepare [law graduates] to participate effectively in the legal profession. ${ }^{, 6}$ This recommendation was adopted immediately. ${ }^{7}$ Several other recommendations of the MacCrate Commission recommended additional self-study and revisions to the standards, and this process was also undertaken, resulting in some stylistic changes at first, then some substantive revisions (effective in 1996). ${ }^{8}$ Among the substantive changes implemented in 1996 was the promulgation of a preamble that specifically identified the

CliniCAL L. ReV. 109, 144-45 (2001) (while acknowledging the difficulty of ascribing motives to changes in law school curricula nationwide, the author suggests that at least in the first five years after the report was published, significant changes in the ABA Standards for Accreditation were adopted, leading to the upgrading of the status of clinical faculty and the professionalization of clinical teaching); Richard A. Matasar, Legal Education: Skills and Values Education: Debate About the Continuum Continues, 22 N.Y.L. SCH. J. INT'L \& ComP. L. 25 (2003) (author suggests that the MacCrate Report has had a substantial, and positive, impact on curricula at law schools, and had improved job status for clinical teachers, but suggesting that much work needs to be done to improve the teaching of several of the skills identified in the MacCrate Report).

On the other hand, some law school deans criticized the MacCrate Report. See, e.g., John J. Costonis, The MacCrate Report: Of Loaves, Fishes, and the Future of American Legal Education, 43 J. LEGAL EDUC. 157, 190 (1993) (criticizing the report for ignoring the cost of implementing its recommendations).

${ }^{6}$ MacCrate report, recommendation C.2. (p. 330).

${ }^{7}$ At the time the MacCrate Report was released, Standard 301(a) read, in full, "A law school shall maintain an educational program that is designed to qualify its graduates for admission to the bar." ABA, Standards for Approval of Law Schools and Interpretations, Standard 301(a) (1992). The following year, that Standard was amended to read, "A law school shall maintain an educational program that is designed to qualify its graduates for admission to the bar and to prepare them to participate effectively in the legal profession." ABA, Standards for Approval of Law Schools and Interpretations, Standard 301(a) (1993).

${ }^{8}$ ABA, 2004-2005 ABA Standards for Approval of Law Schools, p. 5 (2004). 
role of law schools in preparing students to practice law, ${ }^{9}$ and the addition of a requirement that law schools "offer to all students ... an educational program designed to provide its graduates with basic competence in legal analysis and reasoning, legal research, problem solving, and oral and written communication." ${ }^{10}$ Then, in August, 2001, the American Bar Association Board of

${ }^{9}$ The new preamble stated, in relevant part:

The Standards for Approval of Law Schools of the American Bar Association are founded primarily on the fact that law schools are the gateway to the legal profession. They are minimum requirements designed, developed, and implemented for the purpose of advancing the basic goal of providing a sound program of legal education. The graduates of approved law schools can become members of the bar in all United States jurisdictions, representing all members of the public in important interests. Therefore, an approved law school must provide an opportunity for its students to study in a diverse educational environment, and in order to protect the interests of the public, law students, and the profession, it must provide an educational program that ensures that its graduates:

(2) receive basic education through a curriculum that develops:

(ii) skills of legal analysis, reasoning, and problem solving; oral and written communication; legal research; and other fundamental skills necessary to participate effectively in the legal profession[.]

Id.

${ }^{10}$ ABA, Standards for Approval of Law Schools and Interpretations, Standard 302(a)(2) (1996). The 1996 amendments also changed Standard 302's requirement for teaching "professional skills." Previously, it had required that a law school "offer instruction in professional skills;" ABA, Standards for Approval of Law Schools and Interpretations, ?? (1995); in 1996 the ABA amended the standard to require schools to offer "adequate opportunities for instruction in professional skills." ABA, Standards for Approval of Law Schools and Interpretations, Standard 302(a)(4), p. 36 (1997).

For a fuller discussion of the history of changes to the ABA Standards resulting (at least 
Governors adopted yet another revision to Standard 302, requiring, for the first time, "at least one additional rigorous writing experience after the first year." 11

This Article will review the history of the 2001 amendment, and how law schools around the country have responded to it. Part II of this article reviews the amendment and analyzes what curricular changes the ABA may have hoped that law schools adopt in response, concluding that the amendment is likely (or at least should be viewed as) a continuation of a process through which the ABA has attempted to gradually move law schools toward more practical education. Part III will describe a survey of law schools the author conducted during the summer of 2004 which sought to determine how law schools are now attempting to meet Standard 302. Part IV then analyzes the survey data and concludes that many law schools have responded to the amendment, not by requiring any more skills education or practice-oriented writing, but by requiring students to engage in additional academic writing, such as requiring seminar papers, "senior thesis" writing or law review participation. Given the difficulties inherent in judging "rigor" in such settings, the article concludes that this response by law schools does not fairly meet the requirement of the 2001 amendment, and suggests that the timid responses by law schools generally to the 2001 amendment may have been the impetus behind the changes adopted by the $\mathrm{ABA}$ in 2005 to further strengthen the upper-level writing requirement. Part V concludes with several recommendations about how law schools can, at minimal cost, improve the rigor of their existing upper-level writing requirement in order to meet the 2005 interpretation adopted by

arguably) from the MacCrate Report, see Roy T. Stuckey, Education for the Practice of Law: The Times They Are A-Changin', 75 NeB. L. Rev. 649, 655-662 (1996).

${ }^{11}$ American Bar Association, Standards for Approval of Law Schools (ABA 2001), $\S 302(a)(2)$. 
the ABA.

\section{The 2001 Amendment to the ABA Accreditation Standards}

\section{A. A quick look at the ABA accrediting process}

In 1921, the American Bar Association published its first statement of minimum standards for legal education and began publishing listings of law schools that complied with those standards. ${ }^{12}$ The ABA is now recognized by the U.S. Department of Education as the accrediting agency for law schools granting the basic degree, allowing for national standards for law schools around the country. ${ }^{13}$ In the view of the ABA, this centralized accreditation function obviate[s] any need for the individual state courts to evaluate law schools throughout the United States, a role better undertaken by a central body which includes persons from the judiciary, the practice of law and legal education. Ensuring a sound education is necessary to assure a qualified bar. Bar examinations alone are not sufficient to test an applicant's preparation for the practice of law... . The function of the ABA's Standards is to mandate that each student receive the legal training necessary to practice law competently, not merely to pass the bar examination. ${ }^{14}$

The ABA currently fulfills its accrediting function through its Council of the Section of Legal Education and Admission to the Bar. The Council not only recommends changes to the ABA Standards for Approval of Law Schools, ${ }^{15}$ but (after the standards are approved by the

\footnotetext{
${ }^{12}$ American Bar Association, Section of Legal Education and Admissions to the Bar, THE American Bar Association's Role in the Law School Accreditation Process (ABA 1981), at 1.

${ }^{13} I d$. at 4 .

${ }^{14} I d$. at 4-5.

${ }^{15}$ These standards are developed and then proposed by the Standards Review Committee of the Council, which publishes the proposed standards and then conducts public hearings to receive commentary from the legal profession, the academic community, and others.
} 
House of Delegates of the ABA) conducts periodic site inspections of member schools (through its Accreditation Committee) to insure compliance with the standards. ${ }^{16}$

Historically, the ABA Standards on teaching legal writing were more aspirational than mandatory, leaving the schools with broad discretion in how to meet the stated goals. For example, in 1973 the Standards only required law schools to "offer . . . training in professional skills, such as counseling, the drafting of legal documents and materials, and trial and appellate advocacy."17 By 1983 that requirement had changed to a requirement that law schools "shall ... offer to all law students at least one rigorous writing experience." ${ }^{\prime 18}$ That language was not substantially modified until 2001.

\section{B. The 2001 amendment}

As of 2000, ABA Standard 302 included a broad requirement that a law school offer training in legal skills "generally regarded as necessary to effective and responsible participation in the legal profession," rigorous writing experience. ${ }^{20}$ During the 2000-2001 academic year, the Council undertook a

\footnotetext{
${ }^{16}$ American Bar Association, Section of Legal Education and Admissions to the Bar,
} Rules of Procedure for Approval of Law Schools (ABA 2001). For a good overview of the accreditation process, and the interplay of the various constituencies (admitting jurisdictions, law schools, students and the practicing bar) in that process, see generally Ramsey, supra n. 4.

${ }^{17}$ Approval of Law Schools: American Bar Association Standards and Rules of Procedure (ABA 1973), § 302 (a)(ii).

${ }^{18}$ Approval of Law Schools: American Bar Association Standards and Rules of Procedure (As Amended) (ABA 1983), § 302(a)(ii).

${ }^{19}$ ABA Standard 302(a)(1).

${ }^{20}$ American Bar Association, StAndards fOR Approval of LAw Schools (ABA 2000), $\S 302(a)(2)$. 
review of Standard 302, and proposed a change to require that all J.D. students receive "at least one rigorous writing experience in the first year and at least one additional rigorous writing experience after the first year." ${ }^{21}$ In its transmittal to the ABA House of Delegates, the Council explained that the change was needed "to reflect the importance of legal writing instruction in a law school curriculum." 22 The change was adopted by the House of Delegates at its meeting of August 7, 2001..$^{23}$

It is interesting to note that the 2001 amendments changed Standard 302 from aspirational (a requirement only that schools offer such education) to a mandatory requirement that law students actually receive such education. Prior to 2001, Standard 302 required schools only to offer four things: (a) "instruction in substantive law, values and skills," including legal writing; (b) "at least one rigorous writing experience"; (c) "adequate opportunities for instruction in professional skills"; ${ }^{24}$ and (d) live-client clinical opportunities. ${ }^{25}$ The only instruction required by the pre-2001 Standard was in professional responsibility. ${ }^{26}$ The 2001 amendment changed the

${ }^{21}$ American Bar Association, StAndards fOr Approval of LAw Schools (ABA 2001), $\S 302(\mathrm{a})(2)$.

${ }^{22}$ Council of the Section of Legal Education and Admissions to the Bar, Commentary on 2000-2001 Changes to the Standards, Interpretations, and Rules (June, 2001) (copy on file with the author).

${ }^{23}$ Memorandum from John A. Sebert, Consultant on Legal Education to the American Bar Association to law school deans, university presidents and others, dated August 9, 2001 (copy on file with the author).

\footnotetext{
${ }^{24}$ Standard 302(a) (2000).

${ }^{25}$ Standard 302(d) (2000).

${ }^{26}$ Standard 302(b) (2000).
} 
balance by requiring three of these types of instruction: substantive law, legal writing (including the new requirement of an additional rigorous writing experience after the first year) ${ }^{27}$ and professional responsibility. ${ }^{28}$ Professional skills education and live-client clinical experiences remained in the "shall offer" category, ${ }^{29}$ although the 2005 amendment to Standard 302 later moved these to the mandatory "shall require" category. ${ }^{30}$

\section{Interpretation: what was the ABA trying to accomplish?}

It is always difficult to determine the "intent" of any legislative body. Thus, determining what either the Council of the Section of Legal Education and Admission to the Bar, or the ABA House of Delegates, "intended" to accomplish with this amendment is somewhat speculative. ${ }^{31}$ However, the "legislative history" suggests that the 2001 amendment to the Standards was part of a continuing effort to require law schools to focus more on the practical aspects of practicing law and to reduce the perceived "gap" between academia and the practicing bar.

First, the MacCrate report itself suggests a need for additional emphasis on "skills"

\footnotetext{
${ }^{27}$ Standard 302(a) (2001).

${ }^{28}$ Standard 302(b) (2001).

${ }^{29}$ Standard 302(c) (2001).

${ }^{30}$ Standard 302(a)(4) (2005).
}

${ }^{31}$ This is especially true given the process by which the Standards are revised. One commentator described this process as a "consensus validation model" which involves several iterations of committee review, and public hearings before multiple constituency groups (legal educators, judges and practicing attorneys) before the final version is submitted to the ABA's House of Delegates for a vote. Robert K. Walsh, A Global Legal Odyssey: American Bar Association's Standards for the Accreditation of Law Schools, 43 S. TEX. L. REv. 697, 697-8 (2002). Given the fact that input is received from so many sources, and reviewed, interpreted, and acted upon at so many different levels, it is difficult to discern whose "intent" is represented by the final product. 
education; ${ }^{32}$ the 2001 amendment is clearly consistent with that emphasis. Second, the sudden shift from aspirational to mandatory language ${ }^{33}$ suggests a fear that at least some law schools had not been sufficiently rigorous in tending to the skills education component of the curriculum. ${ }^{34}$

An ABA staff member who supported and advised the work of the Council of the Section on Legal Education and Admissions to the Bar also suggests that the intent of the amendment was to encourage additional skills education. Barry Currier, now Dean of the Concord Law School, was the Deputy Consultant on Legal Education for the ABA when Standard 302 was amended in 2001. In that role, he was the ABA staff person assigned to work with the Standards Review Committee of the Council (the "SRC"), although he was not a voting member of that committee. Dean Currier has acknowledged that some members of the legal profession were complaining at that time that too many students were graduating without sufficient writing skills; the amendment to the standard was designed in part to "continue to support the claim that the

\footnotetext{
${ }^{32}$ MacCrate Report, supra $\mathrm{n}$. 1. In particular, the MacCrate report specifically asked the ABA to "clarify" Standard 301 to "affirm that education in lawyering skills and professional values is central to the mission of law schools ...". Also, "the interpretation of Standard 302[] should expressly recognize that students who expect to enter practice in a relatively unsupervised setting have a special need for opportunities to obtain skills instruction." Id., at 330; see also MacCrate Report, Chapter 7 (Professional Development During Law School), id. at 233-272.

${ }^{33}$ See discussion at note 24, supra. The inclusion, in 2005, of "other professional skills generally regarded as necessary for effective and responsible participation in the legal profession" in the category of instruction that law schools "shall require" is further evidence that the ABA continues to press law schools toward requiring more and more practical education. See discussion at note 30, supra.

${ }^{34}$ This is simply an application of the principle of statutory interpretation that postulates that a legislative body, when making a substantial change to the language of a provision, intends some change in the meaning or application of that provision. "When Congress acts to amend a statute, we presume it intends its amendment to have real and substantial effect."See, e.g., Stone v. INS, 514 U.S. 386, 397 (1995).
} 
Standards' requirements did, in fact, do an adequate job of preparing law graduates to begin the practice of law. ${ }^{35}$

However, Dean Currier also suggested that at least some members of the SRC may have believed that this amendment was not particularly substantive, noting that

most schools were already requiring what the Standard now insisted upon. In this case, the Standard trailed, not led, this change. There were certainly a few schools that had to add an upper-level writing requirement or change around the one that they had, but most schools could easily demonstrate compliance with the changed Standard. ${ }^{36}$

The question of whether the SRC "intended" to make a substantive change (toward requiring more rigorous, practical legal writing experiences) or simply intended to document and make explicit what most schools were already doing (in the form of required academic writing) may be impossible to answer. Certainly, given the fact that the SRC is composed of representatives from the academic community, the courts, and the practicing bar $^{37}$, it is quite likely that various members of the committee at that time may have had different reasons for supporting the change. ${ }^{38}$ But there are several reasons to believe that the amendment was in fact

\footnotetext{
${ }^{35} \mathrm{E}$-mail to the author from Barry Currier, dated July 28, 2005 (copy on file with the author).

${ }^{36} I d$.

${ }^{37}$ For 2005-2006, for example, the SRC consists of 13 members: eight deans and law school faculty members, one college president (and former law school dean), two judges, and two practicing lawyers.

${ }^{38}$ There is also the difficulty in determining whose "intent" is being measured here. While the SRC (and the Council) can propose changes, ultimately the changes are adopted by the ABA's House of Delegates, which is dominated by practicing lawyers. It is therefore quite possible, or even likely, that the House of Delegates approved the change upon an entirely different basis than did the SRC or the Council.
} 
an attempt to improve the legal writing abilities of students in a practical context. First, the Committee itself, in its announcement of the change, focused on the need to highlight the "importance of legal writing instruction in a law school curriculum." "39 Second, the ABA Standards have traditionally taken a laissez-faire position with regard to the core academic curriculum of law schools, leaving it to each individual school to determine what courses to offer, how they should be taught, and how they should be evaluated. ${ }^{40}$ Reading this new language as requiring a particular kind of evaluation (a written academic paper as opposed to an examination) would mark a new and unexplained departure from the past practice of allowing schools to decide such matters for themselves. ${ }^{41}$

Finally, the transmittal letter from the Council to the ABA House of Delegates suggests that the Council saw a gap in the practice-oriented side of legal education. In that letter, the Council explained why it chose to require two separate "rigorous writing experiences," one in the first year and one more prior to graduation:

There are, of course, various ways to state an increased requirement, including simply requiring that law schools require two writing experiences rather than one. Many schools might suggest, however, that they meet such a requirement by a two-semester first-year course. Others might suggest that two senior writing

${ }^{39}$ See text accompanying note 22 , supra.

40،"The Standards and Interpretations reflect the general principle that law schools should be given considerable discretion to fashion their own curricula, consistent with their varied and diverse missions." American Bar Association, Section of Legal Education and Admissions to the Bar, Council Statement (viewed at http://www.abanet.org/legaled/council/prior.html).

${ }^{41}$ Indeed, faculty teaching the traditional academic, or "casebook," courses probably do not believe that, in requiring a seminar paper instead of a final examination, they had taken on the additional responsibility for providing additional "legal writing instruction." The casebook teacher will, appropriately, place more emphasis on the substantive analysis, while the legal writing professor will also evaluate the technical aspects writing. See discussion at n. 71, infra. 
seminars would meet such a standard. Neither of those schemes is satisfactory to the Council. The Council believes that a substantial writing experience in the first year is fundamental, and it believes that students will benefit from a writing experience beyond the first year. This increased requirement still leaves law schools with an appropriate amount of flexibility to design programs that fit their student bodies and missions. ${ }^{42}$

Given the historical context in which this amendment occurred, ${ }^{43}$ it is reasonable to conclude that the $\mathrm{ABA}$, in adopting the 2001 revision to Standard 302, was attempting to require that law students receive fuller education in the skill of writing for legal practice. If nothing else, the 2001 amendment was an opportunity for law schools to take another step toward meeting the needs of practicing lawyers.

How did the academy respond to this change?

\section{The Survey}

It may be impossible to examine current law school curricula and determine what changes, if any, were made in direct response to the 2001 amendment. Part of the problem is a lack of detailed "baseline" data as to what writing requirements existed in 2000 or $2001 .^{44}$

${ }^{42}$ Council of the Section of Legal Education and Admissions to the Bar, Commentary on 2000-2001 Changes to the Standards, Interpretations, and Rules (June, 2001) (copy on file with the author).

${ }^{43}$ See text at nn. 4 to 11, supra for a discussion of the incremental changes made subsequent to the publication of the MacCrate Report. Also, while it is of course difficult to prove prior intent through subsequent action, the 2005 amendments to Interpretations 302-1 and 302-2 suggest that the "additional writing experience after the first year" first included in the 2001 amendment may have been intended to require additional practical writing experiences; see discussion at n. 77, infra.

${ }^{44}$ The Association of Legal Writing Directors and the Legal Writing Institute (two professional organizations comprised, respectively, of directors of legal writing programs, and of legal writing professors generally) jointly conduct an annual survey of legal writing programs in all American law schools (hereinafter referred to as the "ALWD/LWI Survey." In 2001, 143 schools ( $82 \%$ of all ABA-accredited schools) participated in the survey. Part V of that survey 
Another part of the problem is that it is impossible to know whether any changes that can be discerned were a result of the amendment to the accreditation standards or due to some other cause. However, it is useful to examine law school curricula several years after the 2001 amendment to discover how law schools now attempt to meet the amended standard, and then to see if these methods are in concert with the ABA's apparent purpose of requiring additional practical writing education.

In order to answer this question, I decided to supplement the annual data gathered by the Association of Legal Writing Directors and the Legal Writing Institute by conducting a more specific survey of accredited schools.

\section{A. Survey methods}

In the summer of 2004, I sent a survey to the legal writing directors at every ABAaccredited law school. ${ }^{45}$ The survey forms requested some "demographic" information about the school, and about the size of the expected incoming freshman class. The survey included questions in three sections. Part I dealt with the current structure of the first-year legal writing program. Part II inquired about upper-level writing requirements, including any required legal writing courses as well as information about how each school fulfills the Standard 302

asked questions about upper-level writing courses offered at each school, but only one question (number 33) directly inquired into whether such courses were required and, if so, what they consist of. Moreover, the question was structured in such a way that schools that require several forms of upper-level writing would be counted multiple times in the total of schools that require an upper-level writing experience; thus, it is not possible from this survey to obtain an unduplicated number of schools participating in the 2001 survey that had some sort of an upperlevel writing requirement.

${ }^{45}$ For schools with directorless legal writing programs, I sent the surveys to the assistant dean for academic affairs, with a letter requesting the dean to forward the survey to a member of the legal writing faculty if he or she could not complete the survey directly. 
requirement for an additional rigorous writing experience after the first year. Part III dealt broadly with how various lawyering skills (generally following the ten "core" skills identified in the MacCrate Report) have been addressed in the law school's curriculum.

The data gathered for parts I and III is designed to create a baseline data set for a future study as to how law schools respond to the current round of amendments to the Article III ABA standards. ${ }^{46}$ The 19 questions in Part II were an attempt to measure, if possible, how law schools responded to the 2001 amendment to Standard 302. This Article reports and analyzes the data gathered in Part II of my survey.

\section{B. Survey responses}

Survey questionnaires were sent to 178 ABA-accredited law schools. Responses were received from 65 schools, a response rate of $36.5 \%$.

Since the 65 respondents constitute a self-selected sample, I compared the sample to the total universe of ABA-accredited law schools in several ways, to determine whether the sample is sufficiently representative to draw meaningful conclusions. The criteria I used were law school size, geographic region, and "ranking." I found that larger schools were slightly overrepresented in the sample of 65 responding schools, ${ }^{47}$ but that the responding schools were spread out

${ }^{46}$ In 2005, the ABA approved additional changes to the Standards and Interpretations; see n. 77, infra. I hope to repeat this survey in four years and compare the results with the baseline data I collected in 2004, to see how law schools have responded to the 2005 amendments.

${ }^{47}$ To evaluate this criterion, I ranked all ABA-approved schools from top to bottom by size of expected entering freshman class. Nearly $28 \%$ of the schools in the sample fell in the top quartile on this scale, and $52.3 \%$ of the sample were in the top half of the size rankings. 
geographically in a fairly representative manner. ${ }^{48}$

Finally, I compared the sample of 65 responding schools to the much-maligned U.S.

News and World Report rankings, to see if the sample was distributed through the "tiers" in relatively equal proportions. ${ }^{49}$ I found that $53.1 \%$ of the sample came from the top two "tiers" of the USNWR list. However, due to ranking ties and the desire for a nice round number for the "Top 100 " list, the top two tiers in the USNWR ranking actually comprise $57 \%$ of the total number of ranked schools, so my sample was slightly under-inclusive of the "top 100."

I also compared the substantive results of my survey to a curriculum survey completed by the American Bar Association published in 2004. In my survey, 54 of 65 responding schools (83\%) said that an "academic paper" satisfied the school's upper-level writing requirement. The ABA's Section of Legal Education and Admissions to the Bar found that (as of 2002, the year after the amendment to Standard 302), 87.5\% of the 152 schools responding to its survey allowed the upper division writing requirement to be satisfied by a seminar paper. ${ }^{51}$ The similarity of

\footnotetext{
${ }^{48}$ To evaluate this criterion, I arbitrarily divided the country into five regions: Northeast, Southeast, Midwest, Southwest, and Mountain/Pacific. I then compared the percentage of ABAapproved schools in each of those regions to the percentage of schools from each region in my sample. All regions except the Southwest fell within $1.5 \%$ of the expected number; the Southwest region was underrepresented by $3.3 \%$.

${ }^{49}$ I do not wish, by using this method, to imply any endorsement of the accuracy or efficacy of the ranking system. I used the tiers simply as a very rough way to see if the sample contained a representative cross-section of schools as measured by this admittedly highly subjective and flawed ranking method.

${ }^{50}$ The under-representation was most significant in the "first tier" (top 50) schools. Whereas the USNWR "top fifty" comprise $28.5 \%$ of all ranked schools, only $23.4 \%$ of my respondents were in the USNWR "top fifty," a shortfall of $5.1 \%$.

${ }^{51}$ American Bar Association, Section of Legal Education and Admissions to the Bar, A Survey of LAw School Curricula, 1992-2002 (ABA 2004).
}

$-18-$ 
those numbers gave me additional confidence that the results reported by my sample were reflective of the larger universe of all ABA-approved schools.

In short, by these measures, the 65 schools which responded to my survey appear to comprise a fairly representative sample of the universe of all ABA-accredited schools.

\section{Supplementation of the data}

Most of the questions in my survey required answers from persons at the school who were knowledgeable about the school's curriculum. However, several questions asked for data that could be readily ascertained from the school's public catalogs and/or the school website. For example, some questions asked about graduation requirements and course offerings; this information is published by most schools on their websites. Thus, in order to gather a more complete data set, I also examined the websites of schools which did not respond to the survey to gather whatever additional data I could.

This expansion of the data set also served as a further "check" on the validity of the respondent sample. For example, one survey question asked how the majority of students fulfilled the requirement of an "additional rigorous writing experience after the first year." Of the 65 respondents, $64.6 \%$ said a seminar paper or law review note satisfied the requirement, while $15.4 \%$ indicated that either an academic paper or an upper-level writing course would satisfy the requirement. In reviewing the websites of the 113 non-responding schools, $66.4 \%$ of the sites revealed that academic papers satisfied this requirement, while $15.0 \%$ of the websites suggested that the requirement was satisfied by either an academic paper or an upper-level writing course. The similarity of these findings suggests yet again that the sample is representative of the whole universe. 


\section{Did the amendment produce the intended result?}

\section{A. How are schools meeting the new requirement?}

Did the 2001 amendment to Standard 302 result in more schools requiring students to learn more about the kind of writing skills that practicing lawyers need? In order to answer that question, it is first necessary to determine what schools offered (and required) prior to the amendment, and then to compare that to what schools now offer and require.

1. Baseline

As noted above, it is somewhat difficult to ascertain what schools were doing as of the 2000-2001 school year, the last academic year before the amendment took effect. One survey, conducted in 1995, suggested that a very large majority of law schools (118 out of 125 responding schools, or 94.4\%) had some sort of an upper-level writing requirement, typically satisfied through the writing of an academic paper for a seminar course or through facultysupervised independent study. ${ }^{52}$ The annual ALWD/LWI survey from 2001 provides more current information. $^{53}$

Question 33 of the ALWD/LWI survey asked whether students at each school were

${ }^{52}$ Lissa Griffin, Teaching Upperclass Writing: Everything You Always Wanted to Know But Were Afraid to Ask, 34 Gonz. L. REV. 45 (1998).

${ }^{53}$ The ALWD/LWI surveys are historically conducted in the spring of the academic year, and report requirements and status of each school's program as of that time. Thus, the 2000-2001 was conducted in the spring of 2001, several months before the Standard 302 amendment was approved by the Council of the Section of Legal Education and Admission to the Bar (June of 2001), and by the ABA House of Delegates (August of 2001).

The ABA's 2002 Survey of Law School Curricula reports the status of curricula as of 2002, the year after Standard 302 was amended, so it does not provide any data as to the state of affairs just prior to the amendment. It does report, however, how schools attempted to meet the new Standard 302 in the first year after it became effective. 
required to satisfy an upper-level writing requirement, "beyond the required program," graduation. The data reported for the 2001 survey did not directly disclose how many schools (of the 143 schools who responded) actually had such a graduation requirement. However, the chart showing the methods used by schools to fulfill the requirement listed two options: "required" and "count toward requirement." A total of 100 schools selected at least one option in the "required" field; however, the survey was constructed so that schools could choose several options as "required." Thus, if a school required more than one of the listed options, the total of the responses may include some duplication (although it is assumed that that number would be fairly small). It is reasonably safe to conclude, however, that no more than 100 schools (approximately $70 \%$ of the respondent pool for that year) had an upper-level writing requirement of some sort as of the 2000-2001 academic year.

The ALWD/LWI Survey data for 2000-2001 does, however, accurately report how many schools accept various forms of advanced legal writing as satisfying the upper-level writing requirement. The results are shown in Table 1, below:

${ }^{54}$ This was apparently a reference to the legal writing program, typically conducted in the first year, that was required by the then-current version of Standard 302. But see text and discussion at footnote 59, infra. 
TABLE 1

Methods of Satisfying Upper-Level Writing Requirement 2000-2001 $1^{55}$

\begin{tabular}{|l|l|l|l|}
\hline Type of writing & Required & $\begin{array}{l}\text { Count toward } \\
\text { requirement }\end{array}$ & Total \\
\hline Advanced course (general writing skills) & 6 & 24 & 30 \\
\hline Advanced course (survey course) & 1 & 10 & 11 \\
\hline Drafting, general & 2 & 22 & 24 \\
\hline Drafting, litigation & 3 & 21 & 24 \\
\hline Drafting, legislation & 2 & 14 & 16 \\
\hline Drafting, transactional & 2 & 24 & 26 \\
\hline Advanced advocacy (excluding moot court) & 3 & 34 & 37 \\
\hline Scholarly writing & 50 & 37 & 87 \\
\hline Judicial opinion writing & 2 & 9 & 11 \\
\hline Advanced research & 7 & 19 & 26 \\
\hline All of the above & 0 & 3 & 3 \\
\hline Other & 22 & 11 & 33 \\
\hline
\end{tabular}

This table shows that the most common way in which a school's "upper-level writing requirement" could be fulfilled in the base year was through scholarly writing. ${ }^{56}$ Since no more than 100 schools in the sample had upper-level writing requirements during that year, the 87

${ }^{55}$ Source: ALWD/LWI 2001 Annual Survey (responses to Question 33) (found at http://www.alwd.org/alwdResources/surveys/surveyNDX.htm\#2001). Note that since there is no unduplicated number available showing how many schools actually had upper-level writing requirements during the 2000-2001 academic year, it is not possible to express these raw numbers in terms of any percentage.

${ }^{56}$ The survey instrument did not define "scholarly writing." Presumably, however, this term may include taking a course which was evaluated by means of a written paper rather than a final examination or other form of testing, as well (in some cases) as participation on a law review. 
schools in the sample which allowed students to fulfill their upper-level writing requirements through the submission of an academic paper represent approximately $87 \%$ of the schools with a writing requirement, and $60.8 \%$ of all of the schools in the sample (all 143 schools that responded).

2. Survey results

So how different is the picture in the 2004-2005 academic year?

Not very. Both my data, and the 2005 responses to the same ALWD/LWI survey, reveal that the situation has not changed much, if at all, as a result of the 2001 amendment. If anything, there appears to be a trend toward more schools accepting academic writing as satisfying the upper-level writing requirement, rather than more practice-oriented writing.

The ALWD/LWI Survey for $2005^{57}$ asked the very same question as the 2001 survey; the results are shown in Table 2:

TABLE 2

Methods of Satisfying Upper-Level Writing Requirement 2004-2005 $5^{58}$

\begin{tabular}{|l|l|l|l|}
\hline Type of writing & Required & $\begin{array}{l}\text { Count toward } \\
\text { requirement }\end{array}$ & Total \\
\hline Advanced course (general writing skills) & 7 & 45 & 52 \\
\hline Advanced course (survey course) & 2 & 21 & 23 \\
\hline Drafting, general & 10 & 38 & 48 \\
\hline
\end{tabular}

${ }^{57}$ Since the 2005 survey took place in the spring of 2005 , it reports conditions present during the 2004-2005 school year. My survey during the summer of 2004 requested data regarding requirements for freshmen entering in the fall of 2004, which is the same period covered by the 2005 ALWD/LWI survey.

${ }^{58}$ Source: ALWD/LWI 2005 Annual Survey (responses to Question 33) (found at http://www.lwionline.org/survey/surveyresults2005.pdf). 


\begin{tabular}{|l|l|l|l|}
\hline Drafting, litigation & 4 & 38 & 42 \\
\hline Drafting, legislation & 1 & 26 & 27 \\
\hline Drafting, transactional & 1 & 43 & 44 \\
\hline Advanced advocacy (excluding moot court) & 5 & 61 & 66 \\
\hline Scholarly writing & 72 & 74 & 146 \\
\hline Judicial opinion writing & 0 & 13 & 13 \\
\hline Advanced research & 9 & 34 & 43 \\
\hline All of the above & $*$ & 17 & 17 \\
\hline Other & 9 & & 9 \\
\hline
\end{tabular}

Several observations are in order here. First, in 2005, 178 schools responded to the ALWD/LWI survey, a remarkable rate of $93 \%$ of all ABA-approved law schools. Second, question 33 of that survey (from which the above information is drawn), first asked whether the school had "an upper-level writing requirement, beyond the required program, for graduation." Of the 169 respondents who answered this question, 148 said yes and, surprisingly, 21 said no.

Given the fact that the revisions to Standard 302 had been in place for nearly four years at the time this survey was put in the field, one would have expected the response rate to have been unanimous; indeed, Standard 302 now requires every student to have an "additional rigorous writing experience after the first year." It is therefore unclear why 21 schools reported no upperlevel writing requirement, other than possible confusion in the wording of the question. ${ }^{59}$

Excluding the 21 respondents who cited no required upper-level writing program, it

${ }^{59}$ For example, respondents may have been confused by the term "required program." Some respondents may have concluded that the term "required program" included the Standard 302 requirement, and that this question was asking about writing requirements which exceeded Standard 302. It is also possible, of course, that some number of these 21 schools have not yet addressed the 2001 amendment to Standard 302. 
appears that approximately $48 \%$ of schools ( 72 of 148 respondents) require an academic paper in order to graduate, and that an additional $50 \%$ allow academic writing to satisfy the upper-level writing requirement. In other words, an overwhelming 98\% of all respondents (146 of 148 schools) now allow the upper-level writing requirement to be satisfied by the writing of an academic paper. ${ }^{60}$

The data from my own survey show similar results.

Since my study was conducted long after the 2001 amendment to Standard 302, I proceeded from the assumption that all schools now required an additional legal writing experience after the first year. (The ALWD/LWI survey question, designed prior to the 2001 amendment and not revised since then, still asks "whether" such a requirement exists.) My

${ }^{60}$ Since the ALWD/LWI survey is conducted annually, it is possible to discern trends. On this question, there appears to be a definite trend towards more schools accepting academic writing as satisfying the upper-level writing requirement. A review of the ALWD/LWI annual surveys for 2002 (the first year after the upper-level writing requirement was added) through 2005 reveal the following:

\begin{tabular}{lrrrr} 
& 2002 & 2003 & 2004 & 2005 \\
\hline$N$ schools with upper-level writing requirement & 126 & 144 & 143 & 148 \\
$N$ schools where academic papers satisfy requirement & 101 & 129 & 130 & 146 \\
\% of schools where academic papers satisfy requirement & $80.2 \%$ & $89.6 \%$ & $90.9 \%$ & $98.6 \%$ \\
& 154 & 172 & 176 & 178
\end{tabular}

Source: ALWD/LWI Annual Surveys, 2002-2005 (found at http://www.alwd.org/alwdResources/surveys/surveyNDX.htm).

It is possible that the large increase in the percentage of schools which accept academic papers as an upper-level writing experience which occurred between 2002 and 2003 is the result of the fact that the response rate for the survey increased significantly (by 18 schools), but this can not fully explain the increase (by 27 schools from 2002 to 2003) which reported that they accepted academic papers. The significant increase (of 16 total schools) which accept academic writing between 2004 and 2005 is clearly unrelated to the increase (of only 2 schools) in the number of schools responding to the survey. 
survey therefore asked more directly about how that requirement was fulfilled by law school curricula, as reflected in Table 3, below.

Table 3 first shows (in the first two columns) the responses from the 65 schools which responded to my survey, then shows (in the middle two columns) the comparable data gathered from my review of 113 additional law school web sites. The final two columns add these two data sources together to reflect how all law schools would have responded to these questions. ${ }^{61}$

TABLE 3

Upper-Level Writing Requirements 2004-200562

\begin{tabular}{ccccll} 
Respondents & \multicolumn{2}{l}{ Non-respondents } & \multicolumn{2}{l}{ Total } \\
$n$ & $\%$ & $n$ & $\%$ & $n$ & $\%$ \\
\hline
\end{tabular}

\section{How many substantial legal writing experiences are students required to complete} after the first year?

$\begin{array}{rrrrrrr}\text { No response } & 2 & 3.1 \% & 0 & 0.0 \% & 2 & 1.1 \% \\ 1 & 42 & 64.6 \% & 84 & 74.3 \% & 126 & 70.8 \% \\ 2 & 19 & 29.2 \% & 21 & 18.6 \% & 40 & 22.5 \% \\ 3 & 2 & 3.1 \% & 8 & 7.1 \% & 10 & 5.6 \% \\ \text { TOTAL RESPONSES } & 65 & & 113 & & 178 & \end{array}$

\section{Please list the required upper-level writing experiences}

$\begin{array}{rrrrrrr}n \text { of responses } & 60 & & 113 & & 173 & \\ \text { Academic paper } & 54 & 90.0 \% & 107 & 94.7 \% & 161 & 93.1 \% \\ \text { Upper-level writing course } & 20 & 33.3 \% & 25 & 22.1 \% & 45 & 26.0 \% \\ \text { Advocacy course } & 14 & 23.3 \% & 10 & 8.8 \% & 24 & 13.9 \%\end{array}$

17. How do the majority of students fulfill the "additional rigorous writing experience after the first year?"

$\begin{array}{rrrrrrr}\text { No response } & 2 & 3.1 \% & 2 & 1.8 \% & 4 & 2.2 \% \\ \text { Seminar paper/law review note } & 42 & 64.6 \% & 82 & 72.6 \% & 124 & 69.7 \%\end{array}$

${ }^{61}$ As noted earlier, the general similarity in the total percentage numbers between the "respondent" and the "non-respondent" schools gives me some comfort that the self-selected sample of 65 responding schools is indeed a representative sample.

${ }^{62}$ Source: Chestek survey of 65 law schools (summer 2004) (results on file with author). 


$\begin{array}{rrrrrrr}\text { Required upper-level writing course } & 4 & 6.2 \% & 4 & 3.5 \% & 8 & 4.5 \% \\ \text { Both paper and a writing course } & 11 & 16.9 \% & 23 & 20.4 \% & 34 & 19.1 \% \\ \text { Required advocacy course } & 2 & 3.1 \% & 1 & 0.9 \% & 3 & 1.7 \% \\ \text { Other combinations of the above } & 4 & 6.2 \% & 1 & 0.9 \% & 5 & 2.8 \% \\ \text { TOTAL RESPONSES } & 65 & & 113 & & 178 & \end{array}$

These data show that, while a good number of schools nationwide (about $28 \%$ ) require more than one writing experience after the first year, in the vast majority of cases $(93.1 \%)$ the writing requirement (either the sole requirement, or one of the two or three requirements) consists of writing an academic paper. ${ }^{63}$ Indeed, the response to survey question 17 , shown above, suggests that nationwide nearly $70 \%$ of schools require only an academic paper in order for a student to satisfy the upper-level writing requirement. ${ }^{64}$

These trends are even more pronounced in the "top tier" schools. For the sake of comparison, I examined the results (both from respondents and non-respondents) for the top 25 schools as ranked by USNWR. ${ }^{65}$ Of that total, 24 schools required an academic paper as a

${ }^{63}$ This could take the form of a paper required as an evaluation method for an academic course, a stand-alone, faculty-supervised "senior thesis" written outside of the context of any particular course, or writing for a law review or law journal.

${ }^{64}$ These findings are not surprising to Dean Currier, the Deputy Consultant on Legal Education at the time of the 2001 amendment. "My experience has been that almost all schools ask students to do something that looks a lot more like academic writing. There is nothing wrong with doing that sort of writing, of course, but it seems to me that we ought to be doing more/better to provide students with a foundation for doing the kinds of writing that they will be called on to do once they are admitted to practice." Currier E-mail to the author, supra n. 35

${ }^{65}$ For 2004 (the year of my study), those schools (in alphabetical order) were: Boston College Law School, Boston University Law School, Brigham Young University-Clark Law School, University of California at Berkeley School of Law, University of California Los Angeles School of Law, University of Chicago School of Law, Columbia Law School, Cornell Law School, Duke University, Georgetown University Law Center, Harvard Law School, University of Iowa College of Law, The University of Michigan Law School, University of Minnesota, NYU, Northwestern University School of Law, Notre Dame Law School, University of Pennsylvania Law School, Stanford Law School, University of Texas School of Law, 
graduation requirement, and one school did not respond to that question (for a $100 \%$ response rate among schools for whom data was collected). The answer to question 17 was similarly unanimous: at all 25 schools, the majority of students fulfill the requirement of an "additional rigorous writing experience after the first year" by writing one or more academic papers. ${ }^{66}$

Size apparently does matter, too. When I examined the responses to question 17 from schools in the top quartile of entering class size, only $84.1 \%$ of schools reported that most students fulfill the requirement through an academic paper. These schools also reported a slightly higher incidence of requiring upper-level writing courses (27.3\%, compared to the national total of $26 \%)$, as well as a higher incidence of required upper-level advocacy courses $(18.2 \%$, compared to the national average of $13.9 \%$ ). This probably reflects the additional resources available to teach such courses at larger schools.

Thus it appears that, while the 2001 amendment to Standard 302 was apparently an attempt to continue the trend towards emphasizing skills education in law schools, it barely moved the needle at all. Both my survey and the ALWD/LWI survey suggest that, in response to the amendment, many schools took the "easy way out" by simply imposing a requirement that, before students graduate, they take at least one course that requires the writing of an academic

Vanderbilt University School of Law, University of Virginia School of Law, Wake Forest University School of Law, Washington and Lee University, and Yale University School of Law.

${ }^{66}$ Excluding the top 25 schools from the nationwide results, 128 of 149 remaining schools for which data could be gathered (85.9\%) reported that most students fulfill the upper-level writing requirement by writing one or more academic papers. This perhaps reflects the fact that schools that may consider themselves among the "elite" schools are more likely to emphasize academics than practical, "skills" type of writing experiences. 
paper instead of a final examination.$^{67}$ Almost no schools elected to add a required upper-level writing course to the curriculum. ${ }^{68}$

\section{B. Does academic writing satisfy Standard 302?}

It is pretty clear, looking at both the ALWD/LWI data and my own survey results, that in the large majority of schools today, students can satisfy the new requirement of "an additional rigorous writing experience after the first year" by writing an academic paper. Even though it is unclear whether this was what the ABA intended when it adopted the new requirement ${ }^{69}$ it seems unlikely that writing such papers is "rigorous" in the same way that a paper written for an upper-level legal writing course would be rigorous.

While, as Dean Currier notes, there is certainly nothing wrong with this kind of writing experience ${ }^{70}$ academic papers have a different purpose, and a different audience, than more practice-oriented writing assignments. This is because the professor evaluating such papers is evaluating students' mastery of the subject matter of the course, not their ability to communicate effectively in writing.

I do not mean to suggest that there is not significant overlap between writing ability and demonstrating mastery of the subject matter; indeed, writing professors frequently teach students

${ }^{67}$ See discussion at n. 60, supra.

${ }^{68}$ Question 12 of the ALWD/LWI annual survey asked schools to disclose what writing courses were required of all students. In the 2001 survey, 31 of 129 schools responding to that question $(24.0 \%)$ reported requiring a third semester of legal writing in the fall. In the 2005 survey, 44 of 170 responding schools $(25.9 \%)$ reported such a requirement (a number virtually identical to my own findings; see Table 3, question 2, supra at n. 62 .

\footnotetext{
${ }^{69}$ See text accompanying n. 38, supra.

${ }^{70}$ See n. 64, supra.
} 
that the process of writing can actually help them think and understand the material they are writing about ${ }^{71}$. My point, instead, is that the linkage between writing ability and understanding of the substantive material is not perfect, and that a student who writes an academic paper poorly yet demonstrates a good grasp of the subject matter may, and should, get a good grade for the substantive law course. Moreover, students writing academic papers for a grade in a substantive course will write in a different voice, with a different style, and in a different form, than they would for a practicing lawyer, or a judge, or a client, or any of the myriad other audiences that a practicing lawyer might need to write for.

The ALWD/LWI surveys also suggest that academic papers are not typically subjected to the same level of rigor as the required legal writing courses. Quantifying the level of "rigor" is a very difficult task, but the ALWD/LWI survey contains some data as to the rigor of the writing experience in "doctrinal" courses (defined by the survey instrument as "a course other than clinics, seminars, or advanced writing courses.") Question 39 of the ALWD/LWI survey asks, "How much written feedback do students generally receive on assignments in doctrinal courses?" The responses to this question from the 2001 and 2005 surveys are reported in Table 4, below:

${ }^{71}$ See, e.g., Joseph Kimble, On Legal Writing Programs, 2 Persp. 1, 2 (1994); Barbara J. Busharis and Suzanne E. Rowe, The Gordian Knot: Uniting Skills and Substance in Employment Discrimination and Federal Taxation Courses, 33 J. Marshall L. Rev. 303, 307-310 (2000); Laurel Currie Oates, Beyond Communication: Writing As a Means of Learning, 6 Leg. Writing 1 (2000). Legal writing professors often conclude that fuzzy writing is indicative of fuzzy thinking, and therefore strive to assist students in clarifying their analysis of the subject matter in order to help clarify their written product. 
TABLE 4

Amount of Feedback for Doctrinal Writing 2001-2005

\begin{tabular}{|lcc|}
\hline & 2001 & 2005 \\
\hline More feedback than in the required writing program & 0 & 0 \\
About the same amount of feedback as in the required writing & 2 & 4 \\
Somewhat less feedback than in the required writing program & 54 & 25 \\
Considerably less feedback than in the required writing program & $*$ & 69 \\
Don't know & 75 & 67 \\
\hline
\end{tabular}

*This was not a listed option in the 2001 survey.

There may be some bias inherent in the answers to these questions, since the ALWD/LWI surveys are generally completed by writing program directors or other faculty members in the legal writing programs. But the findings of the ALWD/LWI survey are entirely consistent with the findings of a 1995 survey that asked more detailed questions about the rigor of academic writing requirements. The authors of that survey found that less than a quarter of the schools with a required academic paper required faculty/student conferences before the first draft of a paper, and that only about a third of those schools required such a conference after the first draft. ${ }^{73}$

Data from my survey is consistent with the ALWD/LWI conclusion. Nearly three quarters $(72.3 \%)$ of the schools responding to my survey said students were not required to submit anything but a final draft for required upper-level writing, while $63 \%$ of respondents said that supervising faculty typically do not read preliminary drafts. ${ }^{74}$

${ }^{72}$ Source: ALWD/LWI 2001 and 2005 Annual Surveys (responses to Question 39) (found at http://www.alwd.org/alwdResources/surveys/surveyNDX.htm). The results are reported above in raw numbers.

${ }^{73}$ Griffin, supra note 52, at 50-55.

${ }^{74}$ Chestek survey of 65 law schools (summer 2004), Part II, questions 9 and 10 (results on file with author). 
Thus, it does seem fair to conclude that the amount of the feedback students receive on academic papers is less than they would receive in a writing course.

This is not a criticism of the faculty teaching seminars and academic courses. Given the other constraints on their time (in terms of research, teaching, and service requirements), and the potentially large number of students who may be writing papers for academic courses, there simply is not enough time in the day for academic faculty to conduct multiple student conferences, read multiple drafts, and give the kind of detailed feedback to students that truly enables them to sharpen their writing skills. ${ }^{75}$ Some faculty would probably resent the additional demands that providing students with a truly "rigorous writing experience" would impose on them, and many of them have no formal training in legal writing instruction.$^{76}$ This is, however, a call for additional resources to be devoted to legal writing education. The ABA in 2001, by requiring the "additional rigorous writing experience," recognized and re-emphasized the importance of developing the writing skills of new law graduates. This cannot be done properly without some cost. Teaching legal writing requires intensive and frequent contact between teacher and student; it cannot be done properly "on the cheap."

The response of academia in general to the 2001 amendment to Standard 301 was a missed opportunity to incrementally implement the basic recommendations of the MacCrate

${ }^{75}$ For a good discussion of how to structure a sound, "rigorous" upper-level writing requirement, see generally Griffin, supra note 52. For a discussion of the importance of revising drafts based upon informed input from a supervisor, see Karl Llewellyn, The Place of Skills in Legal Education, 45 Colum. L. REV. 345, 373 (1945).

${ }^{76}$ Griffin, supra note 52, at 53 (109 of 118 schools responding to a survey question reported that faculty supervising upper-level writing projects receive no formal training in teaching writing). 
Report. Arguably, the ABA agrees. In 2005, the ABA House of Delegates approved several amendments to the Standards and Interpretations. It added Interpretation 302-1 (attempting to define what "rigor" means); ${ }^{77}$ it amended Interpretation 302-2 (previously Interpretation 302-1) to "make[] it clear that the definition of 'professional skills' is broad and includes far more than traditional litigation skills", ${ }^{78}$ and it changed the language of Standard 302 as well. Where previously Standard 302 required students to "receive ... substantial legal writing instruction, including at least one rigorous writing experience in the first year and at least one additional

77 Factors to be considered in evaluating the rigor of writing instruction include: the number and nature of writing projects assigned to students; the opportunities a student has to meet with a writing instructor for purposes of individualized assessment of the student's written products; the number of drafts that a student must produce of any writing project; and the form of assessment used by the writing instructor.

ABA Standards, Interpretation 302-1 (2005).

${ }^{78}$ American Bar Association, Commentary on Revisions to Standards for Approval of Law Schools 2004-2005, p. 6 (2005). The revised Interpretation now reads:

Each law school is encouraged to be creative in developing programs of instruction in professional skills related to the various responsibilities which lawyers are called upon to meet, using the strengths and resources available to the school. Trial and appellate advocacy, alternative methods of dispute resolution, counseling, interviewing, negotiating, problem solving, factual investigation, organization and management of legal work, and drafting are among the areas of instruction in professional skills that fulfill Standard 302 (a)(4).

Id. 
rigorous writing experience after the first year," 79 the 2005 amendment now requires students to receive substantial instruction in writing in a legal context. ${ }^{80}$

It is unclear whether the insertion of the words "writing in a legal context" is meant to distinguish "writing in an academic context." ${ }^{, 81}$ However, in light of the history of amendments to Standard 302 since the MacCrate Report was issued, an argument can be made that this revision is a further attempt by the ABA to nudge law schools toward education in more practice-oriented contexts.

${ }^{79}$ American Bar Association, Standards fOr Approval of LAw Schools (ABA 2001), $\S 302(a)(2)$.

${ }^{80}$ The current language of the Standard 302 reads:

(a) A law school shall require that each student receive substantial instruction in:

(1) the substantive law generally regarded as necessary to effective and responsible participation in the legal profession;

(2) legal analysis and reasoning, legal research, problem solving, and oral communication;

(3) writing in a legal context, including at least one rigorous writing experience in the first year and at least one additional rigorous writing experience after the first year;

(4) other professional skills generally regarded as necessary for effective and responsible participation in the legal profession; and

(5) the history, goals, structure, values, rules, and responsibilities of the legal profession and its members.

American Bar Association, StAndards for Approval of Law Schools (ABA 2005), § 302(a).

${ }^{81}$ The memorandum from John Sebert, the ABA's Consultant on Legal Education, to law school deans claims that this revision merely "restates existing requirements concerning instruction in legal writing." Memorandum of August 23, 2004 (supra n. 23). 
As I suggested at the outset, there is some reason for hope. A number of schools have moved well beyond the requirement of Standard 302 for a first-year legal writing course and a second, usually academic, writing experience. Mercer University, for example, now requires nine credits of legal writing courses over the first three semesters of a law student's career, in addition to an academic writing requirement. ${ }^{82}$ The John Marshall Law School in Chicago has a foursemester required writing program, incorporating not just the objective and predictive writing assignments typical in most first-year curricula, but also requiring upper-level courses in appellate advocacy and contract drafting. ${ }^{83}$ Chicago-Kent College of Law requires five semesters of legal writing courses, one of which is a required academic seminar paper. ${ }^{84}$

While there are some interesting, innovative programs out there, such programs remain the exception rather than the norm. In today's competitive market, however, it will be interesting to see whether the schools that put additional resources into upper-level writing requirements will attract more highly-qualified students.

\section{How Can Schools Improve?}

Requiring additional semesters (beyond the first year) of legal writing is, of course, the gold standard for satisfying the requirement of an additional rigorous writing experience after the first year. It is also perhaps the costliest model, since it would likely require the hiring of additional faculty, although schools which require a third (or more) semester of legal writing may

\footnotetext{
${ }^{82}$ http://www.law.mercer.edu/academics/legal_writing/about.cfm.

${ }^{83}$ http://www.jmls.edu/academics/jd/lawyeringskills.shtml.

${ }^{84} \mathrm{http}: / /$ www.kentlaw.edu/academics/lrw/.
} 
have a marketing advantage in recruiting students because students may view such practiceoriented education as giving them an advantage in the ever-more-competitive job market.

Realistically, however, law school resources are scarce everywhere. Thus, schools are likely to look for the least costly means to satisfy the requirements of Standard 302. Here are a few ideas about how schools might enhance the rigor of the "additional writing experience after the first year" without breaking the bank:

\section{Create a written standard for student work}

The first, and probably simplest, thing that a school might do would be to adopt a uniform statement of what is expected from students. My survey asked schools whether they had "any stated criteria or standards for student work to meet the upper-level writing requirement." While just over $49 \%$ of respondents said they did, a surprising $41.5 \%$ of schools responding to the survey said they had no such criteria. ${ }^{85}$

While it is easy to suggest that, in order to assure "rigor," a school ought to have a uniform standard as to what criteria should be used to evaluate the student's writing, it is much more difficult to decide what those criteria should be. This is because the professors evaluating the writing will likely have entirely different views about what the student is supposed to be learning (and, therefore, what the professor must evaluate). For example, a student who uses a seminar paper in a substantive course to satisfy the requirement will need to prove to the professor's satisfaction that she has mastered the substantive law; the professor evaluating the paper will likely, and properly, give far more weight to the substantive analysis, perhaps to the

${ }^{85}$ Chestek survey of 65 law schools (summer 2004), Part II, question 3 (results on file with author). Two schools, or approximately $3 \%$ of the respondents, said they were in the process of developing such criteria. 
exclusion of the technical writing aspects (what I will call "clarity"). The legal writing professor, whose job is to teach clear legal expression, is likely to give more weight to the clarity of the writing than would the substantive law professor. This is not to say that substantive content is not important to the legal writing professor; in fact, most grading rubrics or criteria used by legal writing professors place great weight on the analysis, or the argument, portion of the writing. That is, a clearly-written paper that misstates the law will (and should) receive a low grade from the legal writing professor. And it is also not to say that bad writing won't affect the grade given by a substantive-law professor; indeed, the bad writing may obscure the writer's point to such a degree that it adversely affects the student's grade. But it is probably true that, if a legal writing professor and a substantive law professor each assigned separate weights (out of 100 points) to substance and to clarity, the legal writing instructor is likely to assign more points for clarity than would the substantive law professor. Both, however, would probably assign more weight to substance than to clarity. And a professor in a live-client clinic program may have still a third different, but entirely valid, set of criteria for grading writing in that context.

Given that, at least in some schools, upper-level writing requirements may be supervised by clinical professors, legal writing professors, or substantive law professors, it would seem that there ought to be some conversation among these groups, and some agreement as to what the faculty as a whole values, in order to assure uniformity and "rigor" in the required writing experience.

The standard could be normative (i.e., "of publishable quality" or some similar verbal standard), procedural (i.e. by requiring multiple drafts, or requiring faculty/student conferences or other forms of faculty feedback), or a combination of the two. For example, the James E. Beasley 
School of Law at Temple University requires all students (since the Class of 1995) to have two upper-level writing requirements: a "serial paper" writing experience (in which the students are required to complete at least four shorter assignments and to receive comments and other feedback from faculty members) and a "research paper" (independent study supervised by faculty which requires research beyond class materials and a substantial, analytical written product) ${ }^{86}$ Written work "of professional quality" for one of the Temple law reviews may or may not be used to satisfy either of these requirements, in the sole discretion of the supervising faculty member. ${ }^{87}$

2. Provide training for doctrinal faculty who must evaluate student work In addition to uniform standards, faculty who supervise upper-level writing experiences might benefit from a frank discussion with the legal writing faculty as to what students have learned in the first-year courses, and how the LRW faculty evaluate student writing. It would be useful for substantive law faculty to understand what a student has been taught in order to allow that faculty member to know what to look for, and to understand why a student may have chosen to write a paper in a particular way.

The obvious benefit of this would be to foster some uniformity in grading, not only between substantive law professors but between the first-year legal writing faculty and the upperlevel evaluators. Complete uniformity is not possible, nor even desirable (since there is always more than one "correct" way to write any paper or brief), but by speaking with a somewhat

\footnotetext{
${ }^{86}$ Jan M. Levine, Supervising Research \& Writing by Upper-Division Law Students (materials prepared for an in-house legal education seminar Nov. 15, 2004, copy on file with the author).

${ }^{87} I d$.
} 
common voice, first-year and upper-level faculty can help students learn to focus on good writing generally and not writing to suit a perceived personal preference of the professor who will be evaluating the work.

In addition, through such an exchange both the legal writing professor and the substantive law professor are likely to gain useful insight into each other's needs. Substantive law professors would get a first-hand look at the theory of rhetoric, as well as educational theory, that support so much of what goes on in the LRW classroom. Legal writing professors would gain insight into what one key audience for their students — the substantive law faculty—look for in student writing. Both parties to the exchange would be enriched thereby.

\section{Move toward Writing Across the Curriculum}

There is, of course, no rule that says the upper level writing experience needs to be an academic paper. Another possible way to provide students with an "additional rigorous writing experience after the first year" would be to include substantial writing components into traditional upper-level courses. ${ }^{88}$

Why couldn't students taking the Business Association course be required to draft a partnership agreement, or corporate by-laws? What if a student taking a course in Intellectual had Property had to draft a licensing agreement? Students taking Professional Responsibility might

\footnotetext{
${ }^{88}$ Numerous commentators have suggested that substantive law courses would benefit from the inclusion of writing assignments. See, e.g., Carol McCrehan Parker, Writing Throughout the Curriculum: Why Law Schools Need It and How to Achieve It, 76 NeB. L. REV. 561 (1997); Busharis, supra n. 71; Alice M. Noble-Allgire, Desegregating the Law School Curriculum: How to Integrate More of the Skills and Values Identified by the MacCrate Report into a Doctrinal Course, 3 NEv. L. J. 32 (2002); Pamela Lysaght and Cristina Lockwood, Writing Across the Law School Curriculum: Theoretical Justifications, Curricular Implications, 2 J. Ass'n Legal Writing Directors 73 (2004).
} 
be asked to draft an ethics opinion; students taking Evidence might draft a motion in limine and a supporting memorandum of law. The possibilities are endless. However, so long as the writing assignments counted towards each student's final grade, and were guided and evaluated by faculty with as much "rigor" as an academic paper might be, there is no reason why this kind of practice-oriented writing could not satisfy the upper level writing requirement.

The benefit to both the student and the substantive law professor of doing this is a fuller and deeper understanding of the substantive material. ${ }^{89} \mathrm{~A}$ student who writes an office memo for her first-year legal writing course on an issue involving, say, intentional infliction of emotional distress is likely to ace any Torts exam question that touches upon that subject. ${ }^{90}$ A practiceoriented writing project is a more active way of engaging the student. It forces students to see the legal doctrine in a very practical way, set among the larger picture of trial (or law firm) procedures. Such assignments can capture a student's imagination and help her picture herself as

\footnotetext{
${ }^{89}$ Mary Beth Beazley Better Writing, Better Thinking: Using Legal Writing Pedagogy in the "Casebook" Classroom (Without Grading Papers), 10 Legal WRITING 23 (2004) (suggesting that adopting legal writing pedagogy in substantive law courses will help students analyze the substantive material and allow substantive law professors to cover material in more depth).

${ }^{90}$ As Dean Byron Cooper has noted:

Samuel Williston and Karl Llewellyn, probably two of the Twentieth Century's greatest commercial law teachers, found that when they got their own contracts students in later courses in commercial law, the students had forgotten what Williston and Llewellyn themselves had taught them in contracts.... But Barbara Woodhouse has pointed out that despite students' memory lapses, they tend to remember with crystal clarity the doctrines they master for their first-year moot court arguments.
}

Byron D. Cooper, The Integration of Theory, Doctrine, and Practice in Legal Education, $1 \mathrm{~J}$. Ass'n Legal Writing Directors 51 (2002) [internal citations omitted]. 
a professional, as well as force her to dig deeper into the material in order to understand its practical implications.

\section{Conclusion}

The new Interpretation 302-1, as well as the revised Interpretation 302-2, has already caused many schools to re-evaluate their upper-level writing requirements. As my survey shows, such scrutiny is long overdue, since many schools do not have a well-defined concept of how to teach or assess upper-level student writing in a rigorous way. In the large majority of law schools, the upper-level writing experiences are assigned, administered and evaluated by substantive law faculty who have no training in critiquing or evaluating the clarity of the student work.

The legal writing faculty, which has the expertise needed to make this requirement a useful educational experience, can and should work with the substantive law faculty to improve the quality of the upper-level writing requirement. The schools that do this well stand to serve the needs of their students, and of the profession generally, the best. 